$1^{\text {st }}$ International Multidisciplinary Conference on Nutraceuticals and Functional Foods

Current Research in Nutrition and Food Science

Vol. 4(SI. 2), 119-124 (2016)

\title{
Fermentation of Cornus mas $L$. Juice for Functional Low Alcoholic Beverage Production
}

\section{CHRYSANTHI NOUSKA, STAVROS KAZAKOS, IOANNA MANTZOURANI, ATHANASSIOS ALEXOPOULOS, EUGENIA BEZIRTZOGLOU and STAVROS PLESSAS *}

\author{
Laboratory of Microbiology, Biotechnology \& Hygiene, Faculty of Agricultural Development, \\ Democritus University of Thrace, Orestiada- 68200, Greece.
}

http://dx.doi.org/10.12944/CRNFSJ.4.Special-Issue-October.16

(Received: August, 2016; Accepted: September, 2016)

\begin{abstract}
Over the last decades there is an increasing demand for consumption of functional foods which claim to provide health benefits. These days the majority of probiotic products are well established by the form of dairy products. However lactose intolerance, cholesterol substances and the increase of vegetarianism lead the research for commercial production, to find new, non-dairy, suitable media for probiotic products. Therefore, a preliminary research has been conducted regarding fermentation of Cornus mas L. juice with one potential probiotic microorganism (Lactobacillus paracasei K5) and one probiotic Lactobacillus plantarum ATCC14917 for functional beverage production. The viability of the aforementioned microorganisms was monitored during fermentation in different $\mathrm{pH}$ values, at $0 \mathrm{~min}, 24 \mathrm{~h}$ and during storage $\left(5^{\circ} \mathrm{C}\right)$ for $1,2,3$ and 4 weeks. The results showed that Lactobacillus. plantarum ATCC 14917 and Lactobacillus paracasei $\mathrm{K} 5$ retained their viability at high levels (at least $6 \mathrm{log} \mathrm{cfu} / \mathrm{ml}$ ) under storage at $5^{\circ} \mathrm{C}$ for 4 weeks, which is considered as an important prerequisite for the characterization of the product as probiotic. Likewise the outcome showed that it is likely to produce a potential functional Cornus mas $L$. beverage with antioxidant activity (due to Cornus mas $L$. ingredients) and potential probiotic activities (due to the potential probiotic strains).
\end{abstract}

Keywords: Functional, probiotic, Cornus mas L., Lactobacillus.

\section{INTRODUCTION}

Consumers demand for functional foods providing health benefits is increasing lately ${ }^{1}$. A significant part of functional foods represented by probiotics (a Greek-derived term meaning "for life") and defined as "live microorganisms that, when consumed in adequate amounts, confer health benefits on the host"2. Probiotic foods contain viable bacteria that can positively affect human or animal health by changing the intestinal microflora ${ }^{3}$. During fermentation and storage, the minimum concentration of live probiotic cells must be $10^{6} \mathrm{cfu} /$ $\mathrm{ml}$, in order to exhibit beneficial properties to the host ${ }^{4}$. These days the majority of probiotic products are well established by the form of dairy products.
However lactose intolerance, cholesterol substances and the increase of vegetarianism lead the research to find new, non-dairy suitable media for probiotic products ${ }^{5}$.

Fruit beverages can be used as vehicles for probiotics due to their high content of sugars, dietary fibre and antioxidant polyphenols ${ }^{6}$.

Cornelian cherry (Cornus mas L.) grows in Southwest Asia and Southern Europe. From the ancient times, cornelian cherry is mentioned as a medical plant ${ }^{7}$. Cornelian cherries are rich in organic acids, sugar and tannins. In comparison with orange, cornelian cherry contains twice amounts of ascorbic acid (vitamin $\mathrm{C})^{8}$. In addition, new research efforts 
showed that this fruits have antibacterial properties against several pathogenic strains, antihistamine, cytotoxic, anti-malarian and anti-inflammatory effects. The aim of this preliminary study was to evaluate the cornelian cherry juice as an alternative fermentation substrate for the production of a potential functional beverage.

\section{MATERIALS AND METHODS}

\section{Preparation of bacteria cultures}

Two Lactobacillus strains were used. Commercial Lactobacillus plantarum ATCC 14917 was the first microorganism applied due to its probiotic abilities ${ }^{9}$. The second microorganism was Lactobacillus paracasei $\mathrm{K} 5$ which was isolated and identified with molecular techniques (PCR-RAPD) in feta type cheese and kefir grains ${ }^{10}$. Lactic acid bacteria cultures incubated into MRS broth (de Man, Rogosa, Sharpe) at $37^{\circ} \mathrm{C}$ for $12 \mathrm{~h}$. the final cultures were harvest by centrifugation at $5000 \mathrm{xg}$ for $5 \mathrm{~min}$ and the resulting bacteria were washed three times with a sterile solution of $\mathrm{NaCl} 0.9 \%(\mathrm{w} / \mathrm{v})$ and one time with Cornus mas L. juice.

\section{Preparation and fermentation of Cornus mas L. juice}

Cornus mas $L$. fruits were heated with double amount of sterilized water until boil and the remaining juice was extracted by filtration and kept for 2 hours in room temperature. The evaluation of $\mathrm{pH}$ was controlled for each sample by adding $\mathrm{NaOH}$ $0.1 \mathrm{M}$. Then the bacteria were added in the fruit juice in enough concentration to reach bacteria counts at least $10^{7} \mathrm{cfu} / \mathrm{ml}$. The samples were incubated for 20 $\mathrm{h}$ at $37^{\circ} \mathrm{C}$ and kept for 4 weeks under cold storage $\left(5^{\circ} \mathrm{C}\right)$.

\section{Lactic acid bacteria enumeration}

The viability evaluated after a serial dilutions of samples in sterile ringer solution. The samples inoculated in petri dishes containing MRS agar and incubated at $37{ }^{\circ} \mathrm{C}$ for $48-72 \mathrm{~h}$ under anaerobiosis. Thereafter, isolated colonies were enumerated and expressed in log cfu/ml. The viable lactic acid bacteria were counted during fermentation on $0 \mathrm{~min}, 24 \mathrm{~h}$ and during storage $\left(5^{\circ} \mathrm{C}\right)$ on $1,2,3$ and 4 weeks.
Determination of total sugar, ethanol and organic acids

The fermented juices in all $\mathrm{pH}$ values were analyzed to determinate total sugars (sucrose, fructose, glucose), ethanol and organic acids (lactic acid, citric acid, acetic acid, propionic acid). Every sample were filtered twice and analyzed in High Performance Liquid Chromatography (Varian) equipped with Refractive Index (RI) detector 356-LC, column Nucleïgel ION 300 OA (Macherey-Nagel). As mobile phase was used sulphuric acid $(0.01 \mathrm{~N})$ with flow rate $0.4 \mathrm{ml} / \mathrm{min}$ and the temperature was adjusted to $45^{\circ} \mathrm{C}$. For each sample the injected volume was 20 ì. All the determinations were done by means of standard curves, and results were the mean of three repetitions.

\section{RESULTS AND DISCUSSION}

\section{Viability of strains during fermentation and storage}

The viability of two Lactobacillus strains in Cornus mas L. juice were monitored during fermentation for 20 hours at $30^{\circ} \mathrm{C}$ and during storage for four weeks at $5^{\circ} \mathrm{C}$. Commercial probiotic Lactobacillus plantarum ATCC 14917 and potential probiotic Lactobacillus paracasei K5 were applied for the fermentation of the juice. The main target was to evaluate the effect of the initial $\mathrm{pH}$ values of the Cornus mas $L$. juice to the viability of the strains keeping the initial sugar concentration approximately stable at $25-28 \mathrm{~g} / \mathrm{l}$.

Preliminary analysis for the determination of viability levels of potential probiotic Lactobacillus paracasei $\mathrm{K} 5$ and commercial probiotic Lactobacillus plantarum ATCC 14917 was conducted. The results showed that an increase of the initial $\mathrm{pH}$ values of Cornus mas $L$. juice may led to higher viabilities of both microorganisms.

Specifically, the results concerning the survival of Lactobacillus plantarum ATCC 14917 during fermentation of Cornus mas $L$. juice for 20 hours at $30^{\circ} \mathrm{C}$ and during storage for four weeks at $5{ }^{\circ} \mathrm{C}$ are presented in Table 1 . There was no significant change in the viability by the end of each fermentation batch regardless the initial $\mathrm{pH}$ value. 
After that the growth kinetic was calculated for four weeks during storage at $5^{\circ} \mathrm{C}$ and the viability determined at high levels. It seems that initial $\mathrm{pH}$ values of the juice does not affect cell viability, since in all the samples of Cornus mas L. juice the viability was more than $6 \mathrm{log} \mathrm{cfu} / \mathrm{ml}$ which is the lower level to characterize the beverage as possible probiotic ${ }^{4}$.

The survival during fermentation for 20 hours at $30^{\circ} \mathrm{C}$ and during storage for four weeks at $5^{\circ} \mathrm{C}$ of Lactobacillus paracasei $\mathrm{K} 5$ inoculated in Cornus mas $L$. juice is shown in Table 2. According to the results, when the initial $\mathrm{pH}$ value of the juice was set at 3.3 the viability of Lactobacillus paracasei K5 was decreased after 20 hours of fermentation. In addition, the viability was constantly reduced after storage of 4 weeks and finally not able to survive. In higher initial $\mathrm{pH}$ values of the juice, Lactobacillus paracasei K5was remain viable and in acceptable levels ( $>6$ log cfu/ml) even by the end of storage proving that initial $\mathrm{pH}$ values set at Cornus mas $L$. juice affects this microorganism.

In summary, Lactobacillus plantarum ATCC 14917 and Lactobacillus paracasei K5 can be applied as potential starter cultures for the production of Cornus mas L. juice with functional properties. However, Lactobacillus paracasei K5 needs higher initial $\mathrm{pH}$ values of Cornus mas $L$. juice than Lactobacillus plantarum ATCC 14917. Therefore, the production of a potential functional Cornus mas $L$. beverage with antioxidant activity (due to Cornus mas $L$. ingredients) and probiotic activities due to the commercial probiotic strain Lactobacillus plantarum ATCC 14917 and the possible probiotic strain Lactobacillus paracasei $\mathrm{K} 5$ seems to be feasible.

In addition 20 untrained panelists were recruited to determine the sensory profile (data not showed) of the fermented juices. For comparison

Table 1: Viability of Lactobacillus plantarum ATCC 14917

supplemented in Cornus mas $L$. juice during fermentation

at $30^{\circ} \mathrm{C}$ for $20 \mathrm{~h}$ and storage at $5^{\circ} \mathrm{C}$ for 4 weeks at

different initial $\mathrm{pH}$ values

\begin{tabular}{lcccc}
\hline & $\begin{array}{c}\text { pH 3.3 } \\
\text { Time }\end{array}$ & \multicolumn{4}{c}{$\begin{array}{c}\text { pH 3.6 } \\
\text { Final counts }(\log \text { cfu/ml) }\end{array}$} & $\begin{array}{c}\text { pH 3.9 } \\
\text { pH 4.2 }\end{array}$ \\
\hline 0 min & $8.08 \pm 0.1$ & $8.38 \pm 0.2$ & $8.76 \pm 0.1$ & $7.95 \pm 0.1$ \\
20 hours & $9.30 \pm 0.1$ & $8.80 \pm 0.1$ & $9.38 \pm 0.2$ & $9.32 \pm 0.2$ \\
1 week & $9.41 \pm 0.2$ & $9.81 \pm 0.2$ & $9.78 \pm 0.1$ & $8.36 \pm 0.2$ \\
2 weeks & $9.00 \pm 0.1$ & $9.69 \pm 0.2$ & $9.04 \pm 0.1$ & $8.77 \pm 0.2$ \\
3 weeks & $8.23 \pm 0.2$ & $8.30 \pm 0.2$ & $8.57 \pm 0.1$ & $8.91 \pm 0.2$ \\
4 weeks & $8.00 \pm 0.1$ & $7.79 \pm 0.2$ & $9.10 \pm 0.2$ & $9.50 \pm 0.1$ \\
\hline
\end{tabular}

Table 2: Viability of Lactobacillus paracasei $\mathrm{K} 5$ supplemented in Cornus mas $L$. juice during fermentation at $30^{\circ} \mathrm{C}$ for $20 \mathrm{~h}$ and storage at $5{ }^{\circ} \mathrm{C}$ for 4 weeks at different initial $\mathrm{pH}$ values

\begin{tabular}{lcccc}
\hline Time & pH 3.3 & $\begin{array}{c}\text { pH 3.6 } \\
\text { Final counts }(\log \text { cfu/ml) }\end{array}$ & pH 4.2 \\
\hline 0 min & $7,48 \pm 0.2$ & $8,18 \pm 0.1$ & $8,15 \pm 0.2$ & $8,40 \pm 0.2$ \\
20 hours & $4,48 \pm 0.2$ & $7,45 \pm 0.2$ & $7,90 \pm 0.1$ & $8,02 \pm 0.1$ \\
1 week & $4,48 \pm 0.1$ & $7,60 \pm 0.1$ & $6,23 \pm 0.1$ & $7,05 \pm 0.2$ \\
2 weeks & $2,30 \pm 0.2$ & $6,70 \pm 0.1$ & $6,64 \pm 0.2$ & $7,64 \pm 0.1$ \\
3 weeks & $1,85 \pm 0.2$ & $6,48 \pm 0.2$ & $6,57 \pm 0.2$ & $7,77 \pm 0.1$ \\
4 weeks & $0 \pm 0.1$ & $6,58 \pm 0.2$ & $7,04 \pm 0.1$ & $7,89 \pm 0.2$ \\
\hline
\end{tabular}


reasons a commercial Cornus mas $L$. juice was also provided. The results showed none significant differences between all the examined fermented juices, which in general were accepted from the panel.

\section{Production of total sugars and organic acids}

Since the viability of Lactobacillus paracasei K5 in fermented Cornus mas L. juice decreased dramatically when the initial $\mathrm{pH} 3.3$, after $20 \mathrm{~h}$ of fermentation, total sugars and organic acids were determined in the fermented batch of Cornus mas L. juice previously set at initial pH value of 3.6 (Table 3). According to the results propionic acid and citric acid were not detected. Acetic acid was not detected at the end of the 20 hours fermentation and during storage was in low concentrations $(<0.1 \mathrm{~g} / \mathrm{L})$. Lactic acid produced after 20 hours of fermentation, while during storage was found at high amounts (up to $11.26 \mathrm{~g} / \mathrm{L}$ ). The concentration of total sugars remained stable through 20 hours of fermentation $(25.03 \mathrm{~g} / \mathrm{L})$ and started to degrease gradually to the end of storage (18.25 g/L) (Figure 1). In addition, small amounts of ethanol were produced at the end of fermentation and till the end of storage the concentration was approximately $0.09 \% \mathrm{v} / \mathrm{v}$. This value ensures that the produced beverage can be characterized as low alcoholic.

Table 3: Chemical composition in Cornus mas L. juice at pH 3.6 fermented by Lactobacillus paracasei K5

\begin{tabular}{lcccc}
\hline Time & Total sugars & $\begin{array}{c}\text { Lactic Acid } \\
\mathbf{g} / \mathbf{L}\end{array}$ & $\begin{array}{c}\text { Acetic Acid } \\
\text { Ethanol } \\
\% \mathbf{v} / \mathbf{v}\end{array}$ \\
\hline Omin & $25,03 \pm 0.1$ & $\mathrm{ND}$ & $\mathrm{ND}$ & $0,01 \pm 0.1$ \\
$20 \mathrm{~h}$ & $25,33 \pm 0.2$ & $4,67 \pm 0.1$ & $\mathrm{ND}$ & $0,05 \pm 0.2$ \\
1 week & $24,45 \pm 0.1$ & $5,87 \pm 0.1$ & $<0,1$ & $0,05 \pm 0.1$ \\
2 week & $23,75 \pm 0.1$ & $6,39 \pm 0.2$ & $<0,1$ & $0,06 \pm 0.1$ \\
3week & $22,94 \pm 0.2$ & $7,03 \pm 0.2$ & $<0,1$ & $0,08 \pm 0.2$ \\
4 week & $18,25 \pm 0.2$ & $11,26 \pm 0.1$ & $<0,1$ & $0,09 \pm 0.2$ \\
\hline
\end{tabular}

${ }^{*}$ ND: Non Detected

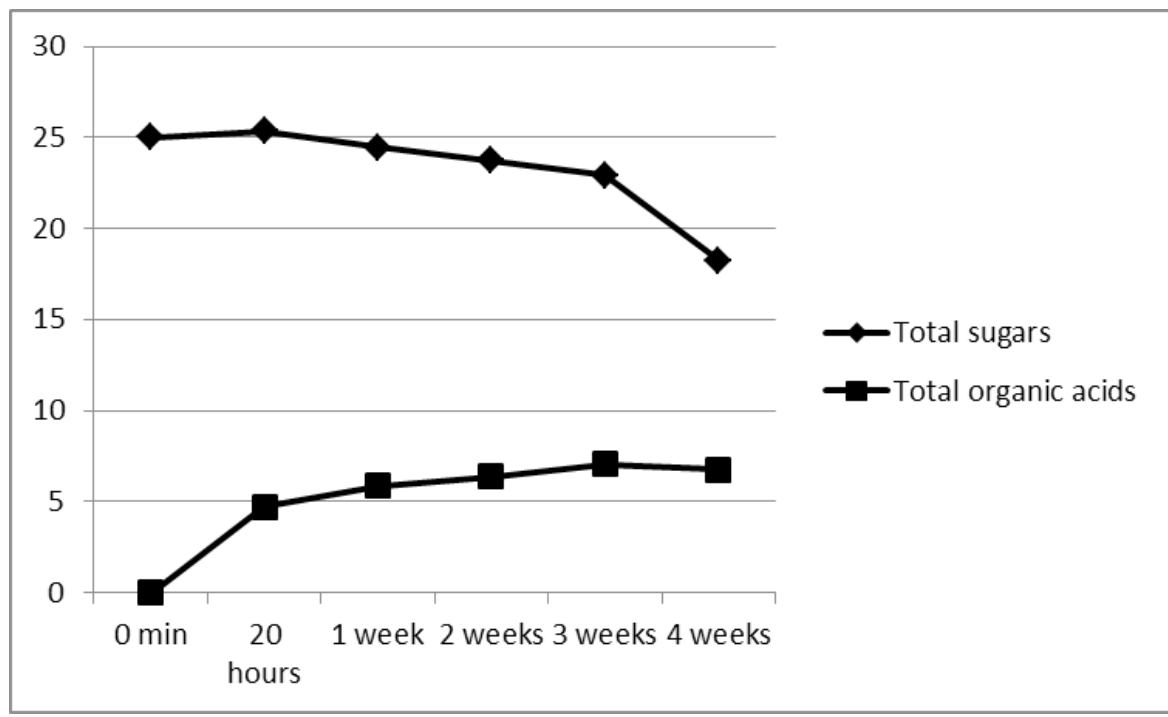

Fig. 1: Changes of total sugar and total organic acids in Cornus mas L. juice at pH 3.6 fermented by Lactobacillus paracasei K5 
Regarding Cornus mas L. juice fermented by Lactobacillus plantarum ATCC 14917, the fermentation batch that was selected for the determination of the total sugar and organic acids was the one that was set at initial $\mathrm{pH}$ value 3.3 (Table 4). The results showed no detection of propionic acid and citric acid. Low amounts of acetic acid were detected at the end of storage $(<0.1 \mathrm{~g} / \mathrm{L})$, lactic acid concentrations were at respectable levels $(23.54 \mathrm{~g} / \mathrm{L})$ and the production of ethanol at the end of storage were determined up to $1.28 \% \mathrm{v} / \mathrm{v}$. It is noteworthy that as the concentration of total sugars decreased, the concentration of total organic acids increased proving good function of the fermentation system (Figure 2).
However, in some occasions the concentration of total sugars may increases due to the hydrolysis of polysaccharides by the action of enzymes ${ }^{11,12}$. This might explain the increase of total sugars of fermented juice by Lactobacillus plantarum ATCC 14917 between the $3^{\text {rd }}$ and the $4^{\text {th }}$ week (Table 4). Scientific evidence regarding the fermentation properties of some lactic acid bacteria strains has recommended that high concentrations of produced organic acids are related with high cell viability due to the metabolism of the available sources of carbon $4,13,14,15$.

Finally more research should be conducted in the near future regarding the oxidative capacity of

Table 4: Chemical composition in Cornus mas L. juice at pH:3.3 fermented by Lactobacillus plantarum ATCC 14917

\begin{tabular}{lcccc}
\hline Time & Total sugars & $\begin{array}{c}\text { Lactic Acid } \\
\mathbf{g} / \mathbf{L}\end{array}$ & Acetic Acid & $\begin{array}{c}\text { Ethanol } \\
\% \mathbf{v} / \mathbf{v}\end{array}$ \\
\hline Omin & $27,76 \pm 0.2$ & $0,21 \pm 0.2$ & $<0,1$ & $\mathrm{ND}$ \\
20h & $24,7 \pm 0.2$ & $13,41 \pm 0.2$ & $0,184 \pm 0.1$ & $0,02 \pm 0.2$ \\
1week & $13,26 \pm 0.1$ & $14,79 \pm 0.2$ & $0,268 \pm 0.2$ & $0,04 \pm 0.1$ \\
2week & $13,84 \pm 0.2$ & $16,74 \pm 0.1$ & $0,326 \pm 0.1$ & $0,06 \pm 0.1$ \\
3week & $4,572 \pm 0.2$ & $16,10 \pm 0.2$ & $<0,1$ & $1,02 \pm 0.2$ \\
4week & $6,141 \pm 0.2$ & $23,54 \pm 0.2$ & $<0,1$ & $1,28 \pm 0.1$ \\
\hline
\end{tabular}

${ }^{*}$ ND: Non Detected



Fig. 2: Changes of total sugar and total organic acids in Cornus mas L. juice at pH:3.3 fermented by Lactobacillus plantarum ATCC 14917 
the produced juices as well as the identification of each microorganism at the fermented juice during storage.

\section{CONCLUSION}

Lactobacillus plantarum ATCC 14917 and Lactobacillus paracasei $\mathrm{K} 5$ can be successfully used as starter cultures for the production of a functional low alcoholic beverage based at Cornus mas $L$. juice. The functional properties of the produced juice are based to the probiotic properties that the applied microorganisms exhibit and to the antioxidative capacity of the juices.

\section{REFERENCES}

1. Prado F.C, Parada J.L, Pandey A, Soccol C.R. Trends in non-dairy probiotic beverages. Food Research International; 41(2):111-123: (2008).

2. FAO/WHO Probiotics in food - Health and nutritional properties and guidelines for evaluation. Rome: Food and Agriculture Organization of the United Nations and World Health Organization expert consultation report; (2006).

3. Bolla P.A, Carasi P, Serradell M.D.L.A, De Antoni G.L. Kefir-isolated Lactococcus lactis subsp. lactis inhibits the cytotoxic effect of Clostridium difficile in vitro. Journal of Dairy Research; 80:96-102: (2013).

4. Ding W.K, Shah N.P. Survival of free and microencapsulated probiotic bacteria in orange and apple juices. International Food Research Journal;15:219-232: (2008).

5. Vasudha S, Mishra H.N, Non dairy probiotic beverages. International Food Research Journal; 20: 7-15: (2013).

6. Seeram N.P, Aviram M, Zhang Y, Henning S.M, Feng L, Dreher M, Heber D. Comparison of antioxidant potency of commonly consumed polyphenol-rich beverages in the United States. Journal of Agricultural and Food Chemistry; 56:1415-1422: (2008).

7. David L, Moldovan B. Extraction, characterization and potential health benefits of bioactive compounds from selected Cornus fruits. In J. P. Owen (Ed.), Fruits and pomace extracts: Biological activity, potential applications and beneficial health effects. New-York: Nova Science Publishers; 157-188: (2015).

8. Seeram N.P, Schutzki R, Chandra A, Nair M.G. Characterization, quantification and bioactivities of anthocyanins in Cornus species. Journal of Agricultural and Food Chemistry, 50: 2519-2523: (2002).

9. Tanabe S. The effect of probiotics and gut microbiota on th17 cells. International Reviews Of Immunology Journal;1-15: (2013).

10. Theodoridou E., Fournomiti M., Nouska C., Alexopoulos A., Mantzourani I., Karapetsas A., Plessas S., Bezurtzoglou E. Determination of probiotic action of lactic acid bacteria isolated from dairy products. International Conference on Chemical and Biological Processes, 19-21 December. Al Barsha Dubai: (2014).

11. Hoebler C, Barry J.L, David A, DelortLaval J. Rapid acid hydrolysis of plant cell wall polysaccharides and simplified quantitative determination of their neutral monosaccharides by gas-liquid chromatography. Journal of Agricultural and Food Chemistry; 37: 360-367: (1989).

12. Mohammad G.A., Andres D.H, Klaus D.K. Isolation of polysaccharides from pineapple fruit pulp and their enzymatic liquefaction. International Food Research Journal; 17: 193-203: (2010).

13. Nualkaekul S, Charalampopoulos D. Survival of Lactobacillus plantarum in model solutions and fruit juices. International Journal of Food Microbiology, 146(2): 111-117: (2011).

14. Kennes C, Dubourguier H.C, Albagnac G, Nyns E.J. Citrate metabolism by Lactobacillus plantarum isolatedfrom orangejuice. The Journal of Applied Bacteriology, 70: 380-384: (1991).

15. Palles T, Beresford T, Condon S, Cogan T.M. Citrate metabolism in Lactobacillus casei and Lactobacillus plantarum. Journal of Applied Microbiology; 85: 147-154: (1998). 